\title{
A floristic analysis of forest and thicket vegetation of the Marakele National Park
}

\author{
P.J. van STAdEN \& G.J. BREDENKAMP
}

Van Staden, P.J. and G.J. Bredenkamp. 2006. A floristic analysis of forest and thicket vegetation of the Marakele National Park. Koedoe 49(1): 15-32. Pretoria. ISSN 00756458 .

One of the major plant communities identified in the Marakele National Park was forest. It became clear that this major forest community contained various forest and thicket communities. Relevés compiled in the forest were classified by TWINSPAN and Braun-Blanquet procedures identified six communities that are hierarchically classified. The forests dominated by Podocarpus latifolius and Widdringtonia nodiflora represent Afromontane Forests, whereas the Buxus macowanii-dominated dry forests and Olea europaea subsp. africana represent Northern Highveld Forests. A further group of communities represent thickets on termitaria with floristic affinities to both savanna and forest. The floristic composition and relationships of the forest and thicket communities are discussed.

Key words: Afromontane forest, Afrotemperate forest, classification, National Park, termitaria, thicket, TWINSPAN.

PJ van Staden, Centre for Wildlife Management, University of Pretoria, Pretoria, 0001 Republic of South Afirca; GJ Bredenkamp $₫$, Department of Botany, University of Pretoria, Pretoria, 0001 Republic of South Afirca (george.bredenkamp@.up.ac.za).

\section{Introduction}

In an overview of the vegetation of Marakele National Park, Van Staden \& Bredenkamp (2005) recognised five major plant communities, of which one represents forests. These forests are mostly restricted to moist, sheltered valleys, and represent typical Marakele Afromontane Forest (Von Maltitz 2003). Although Du Preez et al. (1991) classified this type of forest as typical Afromontane Forests, the Marakele forests exist under much drier conditions than in the Drakensberg (Von Maltitz 2003). These forests occur in specific niches in deep valleys, protected gorges and ravines along the eastern and western slopes of the Drakensberg mountain range.

Indeed, some of the Marakele forests are very dry and represent a very rare and restricted plant community classified by Von Maltitz (2003) under Northern Highveld Forests.
Van Staden (2002) indicated that various plant communities occurred within these forests, though they are not yet described. This paper aims to describe the forest plant communities of the Marakele National Park, to provide an inventory of the biodiversity of the plant community at the plant species level.

\section{Study area}

The study area was described in detail by Van Staden (2002) and Van Staden \& Bredenkamp (2005), and are therefore only briefly mentioned here. The study area covers $290.51 \mathrm{~km}^{2}$ in the southwestern part of the Limpopo Province between $27^{\circ} 30^{\prime} \mathrm{E}-$ $27^{\circ} 45^{\prime} \mathrm{E}$ and $24^{\circ} 15^{\prime} \mathrm{S}-24^{\circ} 30^{\prime} \mathrm{S}$. Marakele National Park is situated mainly in the Waterberg Moist Mountain Bushveld (Low \& Rebelo 1996), in the Savanna Biome (Rutherford \& Westfall 1994). The vegetation of the study area includes Acocks' 
(1988) Sour Bushveld (Veld Type 20), Mixed Bushveld (Veld Type 18), Sourish Mixed Bushveld (Veld Type 19) and NorthEastern Mountain Sourveld (Veld Type 8). The underlying parent rock of the biggest part of the study area consists of sandstone of the Kransberg Subgroup, Sandriviersberg Formation. Sandstone of the Matlabas Subgroup, Aasvoëlkop Formation, occurs in the southwestern and southern parts; shale and mudstone of the Matlabas Subgroup Aasvoëlkop Formation, Groothoek Mudstone Member; a conglomerate outcrop of the Matlabas Subgroup, Aasvoëlkop Formation are found in the western part. These rock formations resulted in the complex mountain topography of the Waterberg. Within this complex topography, the forests are restricted to the relatively moist kloofs, mostly with small rivers.

The soils that have developed on the parent materials range from shallow sandy to deep sandy soils on sandstone and clayey soils on diabase and mudstone.

The rainfall varies from $556 \mathrm{~mm}$ to $630 \mathrm{~mm}$ per annum and occurs mainly during the summer months. This is considerably lower than the rainfall limits described for forests in summer rainfall area by Rutherford \& Westfall (1994). The study area experiences warm, wet summers with temperatures of up to $32{ }^{\circ} \mathrm{C}$ and cool dry winters with frost in the low-lying areas.

\section{Methods}

\section{Analysis}

In the overview of the vegetation of the Marakele National Park, Van Staden (2002) used 130 sample plots, located in a stratified random manner in physiographically and physiognomically homogeneous units, delineated on 1:50 000 scale aerial photographs (Bredenkamp \& Theron 1978; Westfall 1981; Gertenbach 1987). The number of sample plots for each delineated physiographic-physiognomic unit was determined according to the size of each delineated unit. Termitaria were not included in the placing of the sample plots. Although they could be recognised on the aerial photographs, they were too small to delineate. Additional sample plots were subjectively placed within the termitaria vegetation.

For the purpose of this study, a standard sample plot size of $10 \mathrm{~m} \times 20 \mathrm{~m}$ was fixed and used throughout the study area. This plot size is considered adequate for surveys in savanna vegetation by Coetzee (1975), Coetzee et al. (1976), Westfall (1981), Van Rooyen (1983) and Gertenbach (1987).

At each sample plot a list is compiled of all the species that occur. A cover-abundance value was given to each species according to the cover-abundance scale, used by Braun-Blanquet and given by Mueller-Dombois \& Ellenberg (1974) and Werger (1974), and modified by Barkman et al. (1964):

5 - Any number of plants, with cover $>75 \%$ of the sample plot.

4 - Any number of plants, with cover $>50-75 \%$ of the sample plot.

3 - Any number of plants, with cover $>25-50 \%$ of the sample plot.

2a - Covering between 5-12\% of the sample plot area independent of abundance (indicated as A in the tables).

$2 \mathrm{~b}$-Covering between $13-25 \%$ of the sample plot area independent of abundance (indicated as B in the tables).

1 - Numerous, with cover of $5 \%$ or less.

+ - Individuals with cover of $<1 \%$.

$r$ - Usually a single individual with a cover of $<1 \%$.

Although Van Staden (2002) recorded various habitat variables, only the following habitat classes are used in this study (see Table 1):

The altitude of each sample plot was recorded using an altimeter and is given in meters.

The slope of the terrain of each sample plot was measured in degrees, using an optical clinometer. The following classification of slope units (Westfall 1981), were used in this study:

\begin{tabular}{lll} 
Symbol & Description & Class \\
\hline $\mathrm{L}$ & level & $0.00^{\circ}-3.49^{\circ}$ \\
$\mathrm{G}$ & gentle & $3.50^{\circ}-17.62^{\circ}$ \\
$\mathrm{M}$ & moderate & $17.63^{\circ}-36.39^{\circ}$ \\
$\mathrm{S}$ & steep & $36.40^{\circ}$ \\
\hline
\end{tabular}

The aspect of the terrain where each sample plot is situated was determined using a compass. Aspect is given in the eight compass directions, namely:
$\mathrm{N}$ - North
S - South
NE - Northeast
SW - Southwest
E - East
W - West
SE - Southeast 
The surface rock cover in each sample plot was estimated as a percentage of stones ( $>20 \mathrm{~mm}$ diameter), boulders and rocky outcrops. The following five classes were used, based on its potential influence on mechanical use (ploughing) (Van der Meulen 1979; Westfall 1981):

\begin{tabular}{lll}
\multicolumn{1}{c}{ Symbol } & Class & Description \\
\hline $\mathrm{O}$ & $<1 \%$ & $\begin{array}{l}\text { No limitation on mechanical } \\
\text { utilisation }\end{array}$ \\
$\mathrm{L}$ & $1-4 \%$ & $\begin{array}{l}\text { Low limitation on mechanical } \\
\text { utilisation } \\
\text { Moderate limitation on } \\
\text { mechanical utilisation }\end{array}$ \\
$\mathrm{M}$ & $5-34 \%$ & $\begin{array}{l}\text { High limitation on mechanical } \\
\text { utilisation } \\
\text { No mechanical utilisation } \\
\text { possible }\end{array}$ \\
V & $35-84 \%-100 \%$ & \\
\hline
\end{tabular}

Land type was read from the Land Type maps.

\section{Synthesis}

The full dataset was captured on the mainframe computer of the University of Pretoria, in the BBNEW software package. It was then exported to be used in the software package BBPC (Bezuidenhout et al. 1996). After a TWINSPAN classification (Hill 1979), the output of the resulting classification was imported into a spreadsheet, for refinement by Braun-Blanquet procedures (Behr \& Bredenkamp 1988). The final classification of the relevés was then interpreted for identification of major communities for the entire park. The relevés representing the forests and thickets were then extracted, subjected to TWINSPAN (Hill 1979) and exported to be used in the software package BBPC (Bezuidenhout et al. 1996) for refinement by Braun-Blanquet procedures. The results are summarised in a phytosociological table (Table 1).

\section{Results}

The phytosociological classification of forests and thickets in the study area resulted in the identification of five forest communities with one of the communities having two sub-communities.

\section{Olea europaea subsp. africana-Diospyros whyteana Major Community}

Van Staden \& Bredenkamp (2005) identified the forest and thicket vegetation that occur on the Marakele National Park as the Olea europaea subsp. africana-Diospyros whyteana Major Community. Obvious variation in plant species composition and dominance was observed within this major community. The floristic composition of the Olea europaea subsp. africana-Diospyros whyteana Major Community is given in Table 1.

Van Staden \& Bredenkamp (2005) described this major community as having a large number of diagnostic species, all being trees or shrubs, which distinguish this forest vegetation from any other plant community occurring in the park. These diagnostic species included Pappea capensis, Mimusops zeyheri, Olea europaea subsp. africana, Cussonia paniculata, Diospyros whyteana, Euphorbia ingens, Rhus leptodictya, Cryptolepis transvaalensis, Podocarpus latifolius, Maytenus undata, Zanthoxylum capense, Myrsine africana, Canthium gilfillanii, Ficus sur, Calpurnia aurea, Olea capensis and Grewia occidentalis.

Although different plant communities can be recognised within these forests and bush clumps, certain species, e.g., Olea europaea subsp. africana, Ficus sur, Cryptolepis transvaalensis, Cussonia paniculata and Euphorbia ingens were prominent throughout the range of this major community.

The forest communities occur in the kloofs, or as thickets in bush clumps on south and east-facing slopes and also as dense thickets on termitaria on the plains. The kloofs are the most sheltered of the geomorphology classes found in the study area, with water in the watercourses draining down the kloofs. These kloofs are also protected against the veld fires that occur frequently in the adjacent savanna or grassland vegetation. Geldenhuys (1994) described a similar situation for forests in the Western Cape.

Coetzee (1975) described a related community from the Rustenburg Nature Reserve as Hypoestes verticillaris-Mimusops zeyheri Forests, and Westfall (1981) described a similar community from the Farm Groothoek in the Waterberg as Kloof Forest Communities on moderately deep soils in moist, sheltered 


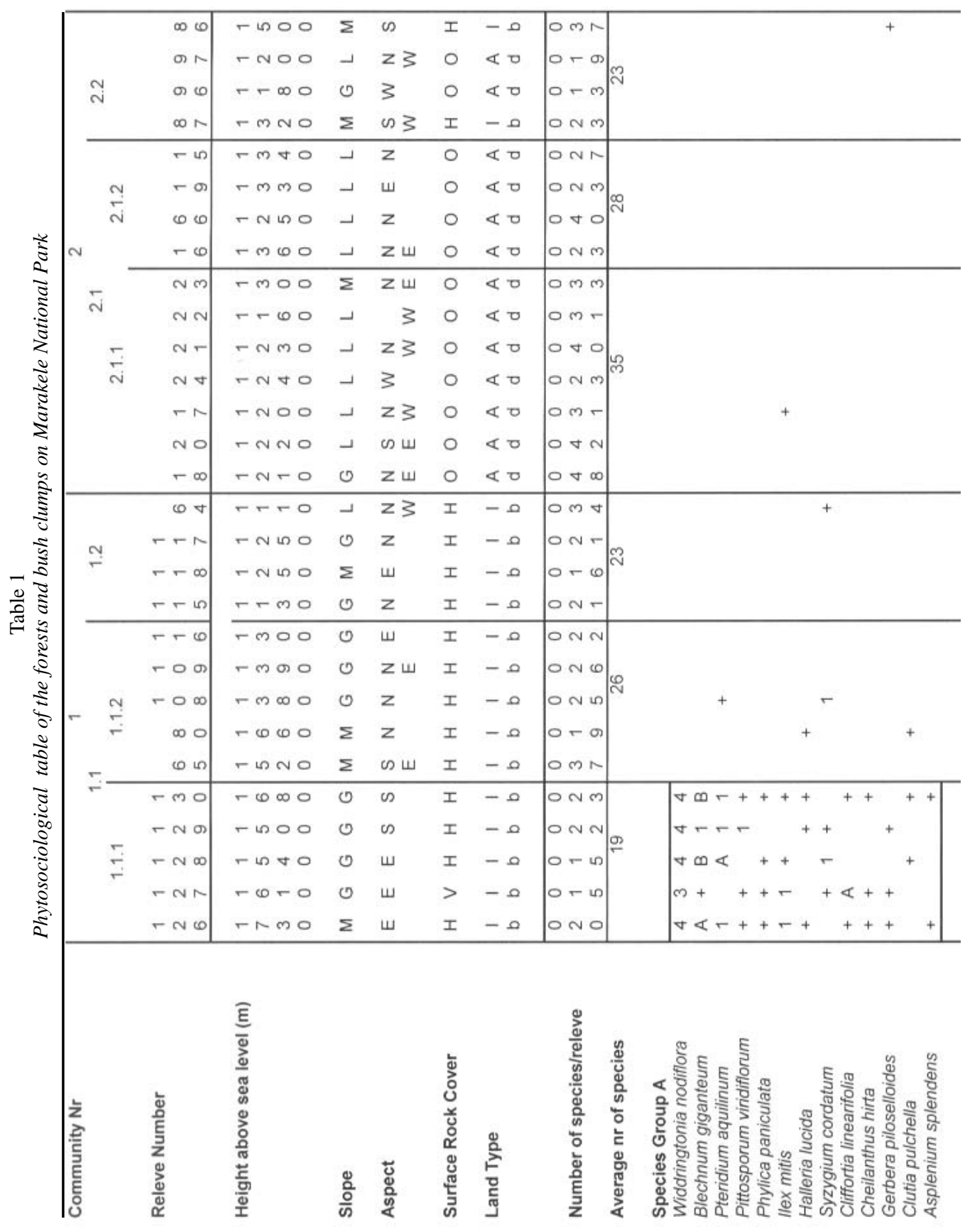



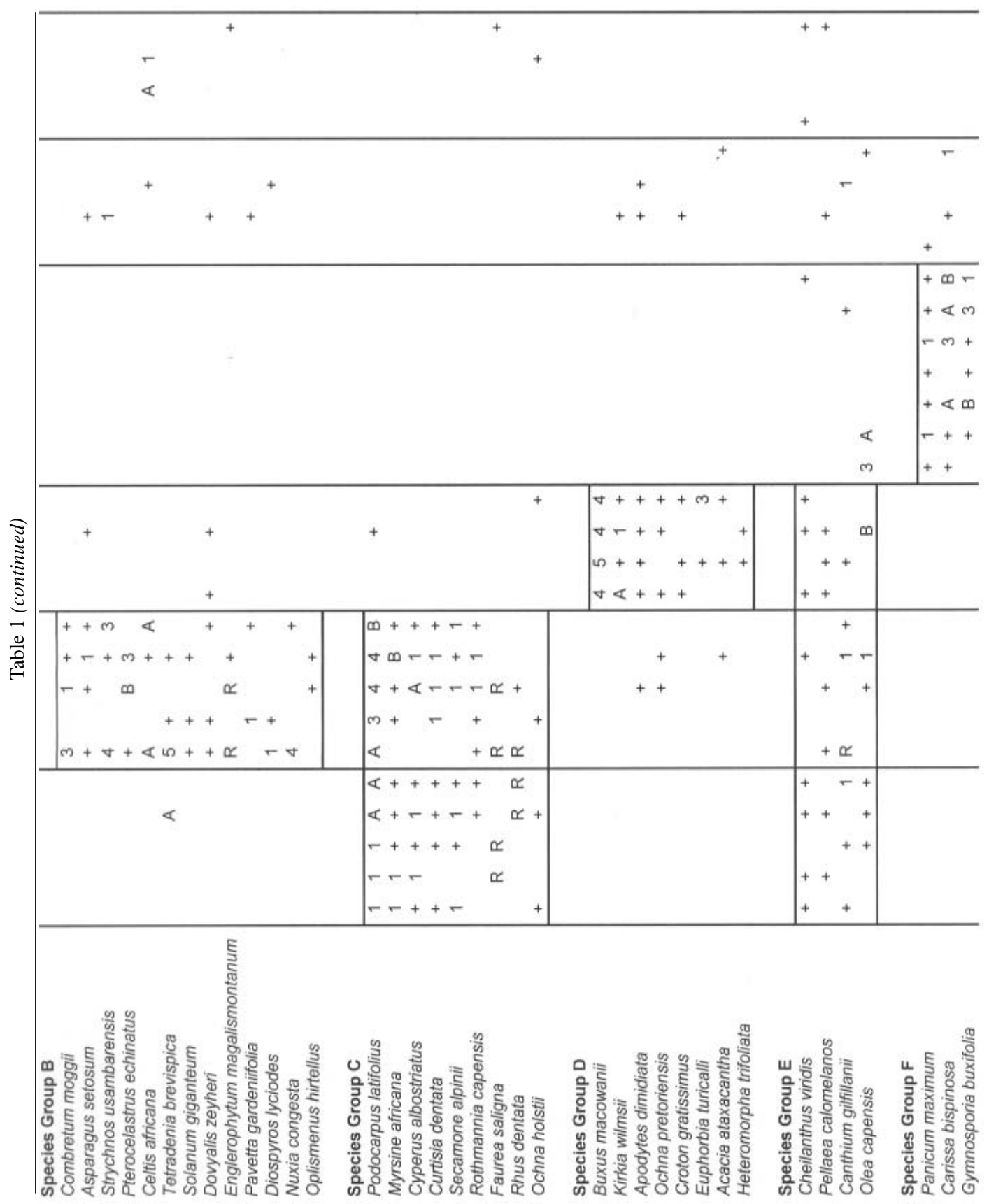

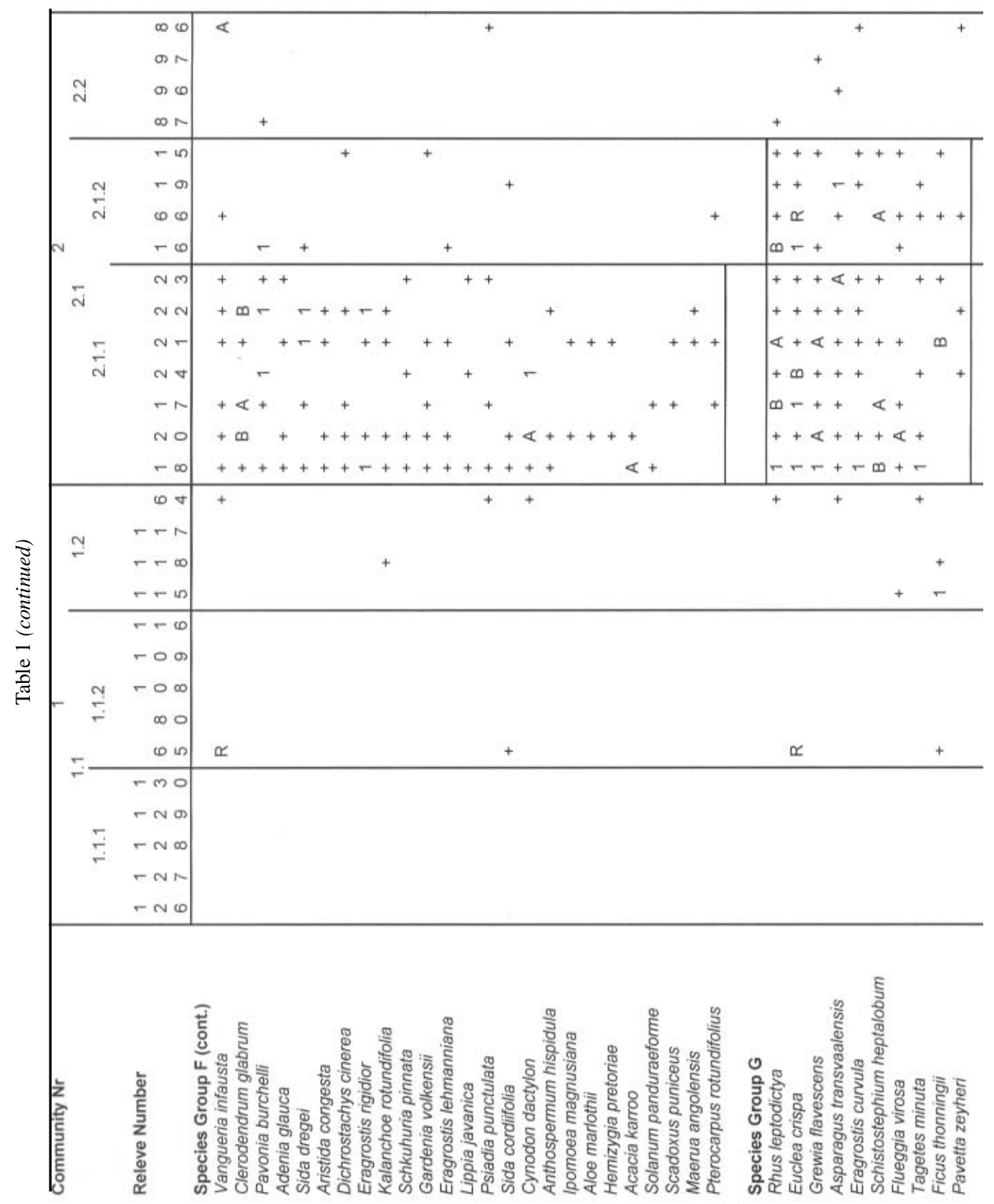

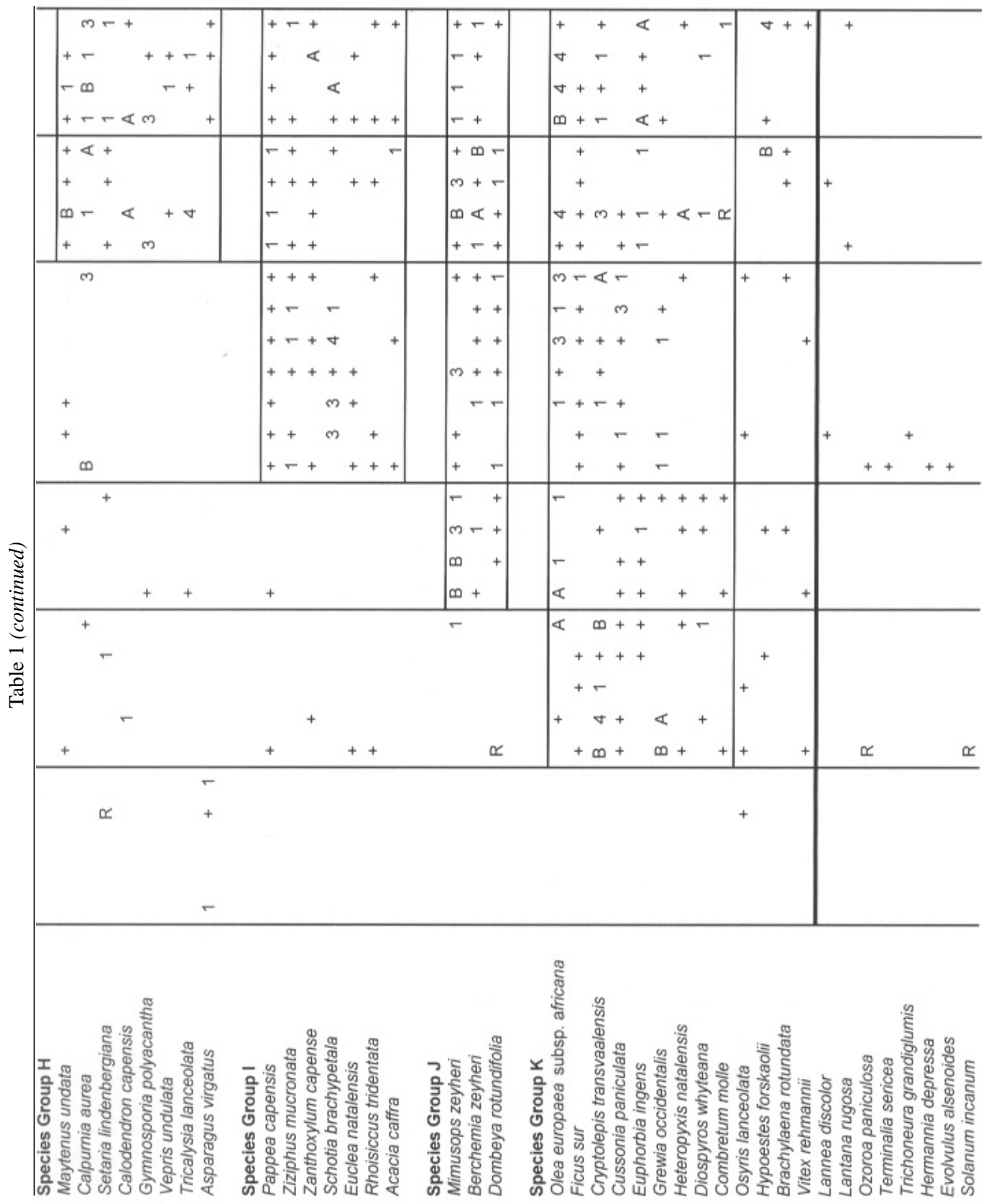


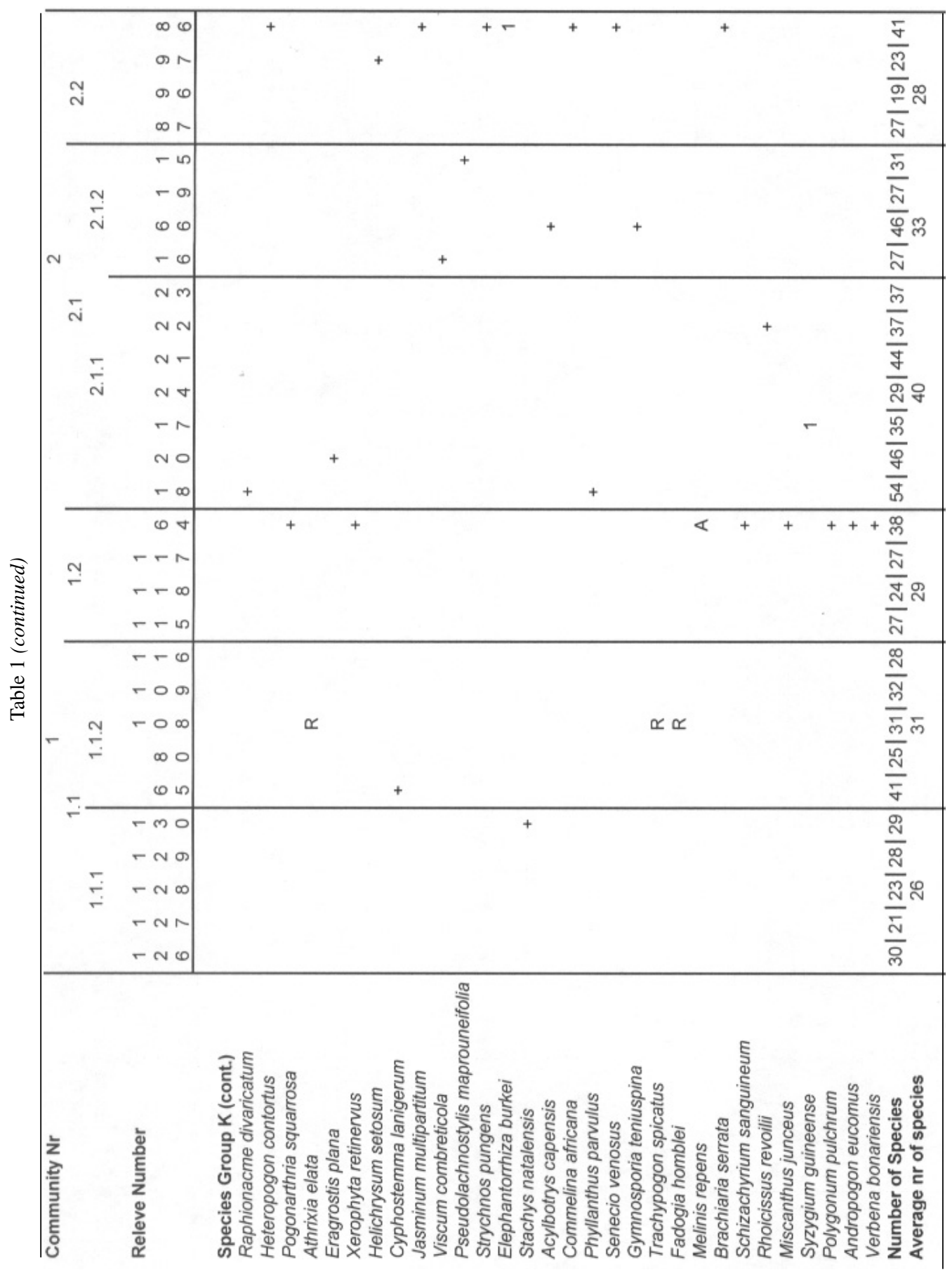


habitats. Du Preez et al. (1991) classified this type of forest as typical Afromontane Forests, where these forests occur in specific niches in deep valleys, protected gorges and ravines along the eastern and western slopes of the Drakensberg mountain range. Coetzee et al. (1976) described termitaria bush clump communities from the Nylsvley Nature Reserve. These have diagnostic species similar to the bush clump communities on termitaria in the Marekele National Park.

In the hierarchical phytosociological classification, the following plant communities are classified under the Olea europaea subsp. africana-Diospyros whyteana Major Community (Table 1):

1 Olea capensis-Cheilanthes viridis Forest

\subsection{Podocarpus latifolius-Curtisia dentata} Forest

1.1.1 Widdringtonia nodifloraPodocarpus latifolius Moist Short Forest.

1.1.2 Podocarpus latifolius-Rothmannia capensis Moist Tall Forest.
1.2 Buxus macowanii-Kirkia wilmsii Dry Low Forest.

2 Pappea capensis-Ziziphus mucronata Thickets and Bush Clumps

2.1 Rhus leptodictya-Mimusops zeyheri Termitarium Thickets.

2.1.1 Rhus leptodictya-Carissa bispinosa sub-community

2.1.2 Rhus leptodictya-Berchemia zeyheri sub-community

2.2 Olea europaea subsp. africana-

Calpurnea aurea Tall Closed Woodland.

A dendrogram showing the habitat relationships of the various plant communities is shown in Fig. 1.

\section{Olea capensis-Cheilanthes viridis Forest}

This community represents all the forests that occur in moist kloofs or sheltered valleys in the Marakele National Park. Based on species composition, this vegetation can be regarded as Afromontane Forest (White 1978). According to the classification of

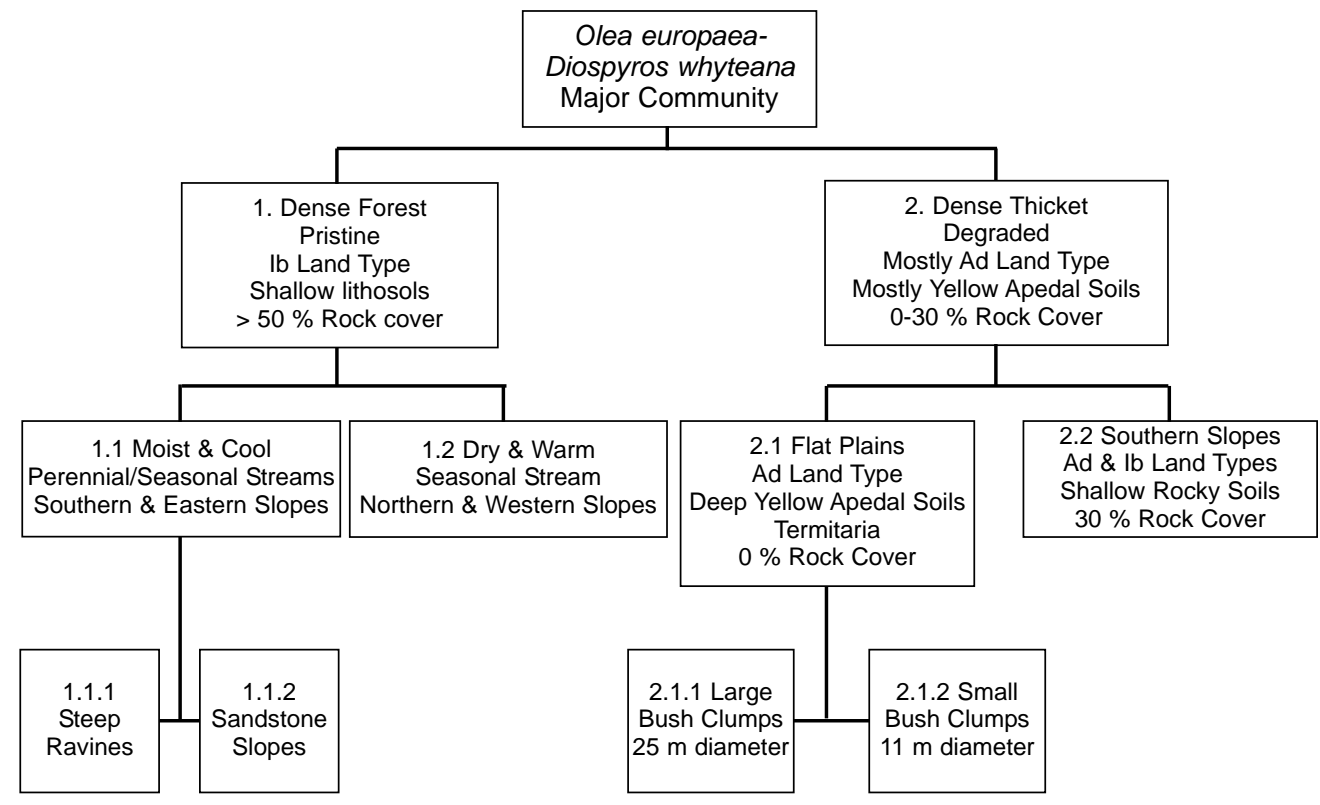

Fig. 1. A dendrogram showing the habitat relationships of the plant communities classified under the Olea europaea- subsp. africana-Diospyros whyteana Major Community. 
South African forests by Von Maltitz (2003), the forests of the Waterberg area represent Marakele Afromontane Forests and Northern Highveld Forests, both these types being classified under the Northern Afrotemperate Group of forests. The Olea capensisCheilanthes viridis Forest represents a northwestern island of Afromontane (White 1978) or Afrotemperate (Von Maltitz 2003) forests.

Within the study area this community is characterised by species group E (Table 1), with the trees Olea capensis and Canthium gilfillanii and the ferns Cheilanthus viridis and Pellaea calomelanos as the diagnostic species. Olea capensis, in particular, can be regarded as a typical forest species, though the other three species may occur widespread on rocky areas of the Waterberg and Bankenveld (Bredenkamp \& Brown 2003; Van Staden \& Bredenkamp 2005).

These forests can be subdivided into Podocarpus latifolius-Curtisia dentata Forest, restricted to moist, sheltered valleys, and representing typical Marakele Afromontane Forest (Von Maltitz 2003), and Buxus macowanii-Kirkia wilmsii Dry Low Forest, a very specialized dry forest, representing a very rare and restricted plant community classified by Von Maltitz (2003) under Northern Highveld Forests.

\subsection{Podocarpus latifolius-Curtisia dentata Forest}

These forests represent the typical moist short to tall forests of the Waterberg area,

Tall Forest is found at $1300 \mathrm{~m}-1730 \mathrm{~m}$ a.s.l. along perennial or seasonal streams and moist kloofs. This forest community is a representative of North-Eastern Mountain Sourveld (Acocks 1988), Afromontane Forest (White 1978) and typical Marakele Afromontane Forest (Mucina \& Van Staden 2003), classified under the Northern Afrotemperate Forest Group (Von Maltitz 2003). This is a local forest type found only on the Waterberg, Marakele National Park (Van Staden 2002) and some kloofs of Magaliesberg (Coetzee 1975).
These Northern Afrotemperate Forests are, according to Von Maltitz (2003), restricted to mountains and low ridges (Strydpoortberg, Waterberg, Pilanesberg, Witwatersrand, Magaliesberg, Suikerbosrand, Sekhkukhuneland) interrupting the relatively flat northern highveld grassland or bushveld. The forests are found in kloofs on the northern and eastern flanks of the Drakensberg.

The diagnostic species of Podocarpus latifolius-Curtisia dentata Forest are listed under species group $\mathrm{C}$, with the trees Podocarpus latifolius, Curtisia dentata, Rothmannia capensis, Faurea saligna, Rhus dentata, Myrsine africana and Ochna holstii, the liana Secamone alpinii and the sedge Cyperus albostriatus as diagnostic species. The tall-growing Podocarpus latifolius is mostly the dominant species, locally reaching a cover of up to $70 \%$.

\subsubsection{Widdringtonia nodiflora-Podocarpus latifolius Short Forest}

Typical: relevé 130

Habitat

The Widdringtonia nodiflora-Podocarpus latifolius Short Forest is found at high altitudes, $1500 \mathrm{~m}-1730 \mathrm{~m}$ a.s.l. along perennial streams and deep, sheltered, moist kloofs, on gentle to moderate $\left(6-22^{\circ}\right)$ east and southfacing sandstone slopes within the Ib Land Type. The soils are of the Mispah Form derived from sandstone of the Sandriviersberg Formation, and the soil is relatively shallow (<500 mm) (Land Type Survey Staff 1988).

Although this community is not totally protected from fire, the woody vegetation and structure are seldom damaged due to the poorly developed grass layer and the high percentage rock cover that provides shelter against fire. Large rocks cover more than $76 \%$ of the soil surface. During the rainy season and for some time thereafter, water constantly seeps from the sandstone, creating an ideal moist habitat where this community is typically found. 


\section{Floristics and structure}

The Widdringtonia nodiflora-Podocarpus latifolius Short Forest is differentiated by the following diagnostic plant species (species group A, Table 1): the woody Widdringtonia nodiflora, Pittosporum viridiflorum, Ilex mitis, Halleria lucida, Syzygium cordatum and Cliffortia linearifolia; the shrubby Clutia pulchella and Phylica paniculata; the ferns Blechnum giganteum, Pteridium aquilinum, Asplenium splendens and Cheilanthus hirta; and the forb Gerbera piloselloides.

This community is represented by five relevés and an average of 19 species was recorded per sample plot.

The tree layer is on average $8.4 \mathrm{~m}$ tall with an average canopy cover of $79 \%$ (Table 2). Widdringtonia nodiflora is totally dominant, whereas Podocarpus latifolius may locally be very prominent. Apart from the diagnostic woody species, other prominent trees are Curtisia dentata, Canthium gilfillanii (species group C), and Olea capensis (species group $\mathrm{E}$ ). The latter species has a wider distribution within various forest communities in the park (Table 1).

The shrub layer is on average $1.4 \mathrm{~m}$ tall, with an average canopy cover of $22 \%$ (Table 2). Prominent shrubs occurring in this community are Myrsine africana and Ochna holstii (species group C) (Table 1). The woody liana Secamone alpinii (species group C) is frequently found in the tree and shrub strata.

The herbaceous layer has an average height of $0.5 \mathrm{~m}$ and an average canopy cover of $11.0 \%$ (Table 2). It is dominated by the diagnostic ferns Blechnum giganteum, Pteridium aquilinum and Asplenium splendens (species group A) and the sedge Cyperus albostriatus (Species Group C) as ground cover in the more open areas. The tree fern, Cyathea dregei, which was not recorded in any sample plots, also occurs as isolated individuals in the forests in the study area.

\section{General}

The Widdringtonia nodiflora-Podocarpus latifolius Short Forest has many characteris- tic species in common with the Ilex mitisPittosporum viridiflorum Forest Community described by Coetzee (1975) and the Kloof Forest Communities described by Westfall (1981). This community occupies the most mesic habitats of sheltered parts of kloofs on the eastern side of the Waterberg Mountain. The dominant woody species Widdringtonia nodiflora and Podocarpus latifolius are, however, absent from the forest communities described by Coetzee (1975).

Communities 1.1.1 and 1.1.2 are floristically related through the mutual presence of the species of species group $\mathrm{B}$, emphasised especially by Podocarpus latifolius, Curtisia dentata, Rothmannia capensis and Myrsine africana. These forests are also remotely related to Buxus macowanii-Kirkia wilmsii Low Forest (Community 3), through species group E (Table 1).

\subsubsection{Podocarpus latifolius-Rothmannia capensis Tall Forest.}

Typical: relevé 109

\section{Habitat}

The Podocarpus latifolius-Rothmannia capensis Tall Forest is found at $1300 \mathrm{~m}-$ $1660 \mathrm{~m}$ a.s.l. along perennial or seasonal streams and moist kloofs on sandstone slopes $\left(4-30^{\circ}\right)$, facing southeast, north, northeast and east. It is represented by five relevés and an average of 26 species was recorded per sample plot. This forest community is a representative of Acocks' (1988) North-Eastern Mountain Sourveld, with the structure as a tall forest (Edwards 1983) and it all occurs in the Ib Land Type (Land Type Survey Staff 1988).

During the rainy season and for some time thereafter water constantly seeps from the sandstone, creating an ideal moist habitat, characteristic for this community. The soils are of the Mispah Form derived from sandstone of the Sandriviersberg Formation, and the average soil depth is relatively shallow (<500 mm) (Land Type Survey Staff 1988). Large rocks cover more than $70 \%$ of the soil surface. 


\section{Floristics and structure}

The Podocarpus latifolius-Rothmannia capensis Tall Forest is differentiated by the diagnostic following plant species (species group B, Table 1): the woody Combretum moggii, Strychnos usambarensis, Pterocelastrus echinatus, Celtis africana, Tetradenia brevispica, Solanum giganteum, Dovyalis zeyheri, Englerophytum magalismontanum, Pavetta gardeniifolia, Diospyros lycioides and Nuxia congesta; the herbaceous Asparagus setosum; and the grass Oplismenus hirtellus.

The tree layer is on average $12 \mathrm{~m}$ tall with an average canopy cover of $79 \%$. Other prominent trees are Pittosporum viridiflorum (species group A), Podocarpus latifolius and Curtisia dentata (species group C), Cussonia paniculata, Ficus thonningii, Olea europaea subsp. africana, Euphorbia ingens, Ficus sur (species group K), Mimusops zeyheri (species group J), and Olea capensis (species group E). The tree fern Cyathea dregei, which was not recorded in the sample plots, also occurs in this community.

The shrub layer is on average $1.7 \mathrm{~m}$ tall with an average canopy cover of $49 \%$. Apart from the diagnostic species, other prominent shrubs occurring in this community are Myrsine africana (species group C), Canthium gilfillanii (species group E), and Diospyros whyteana and Grewia occidentalis (species group K). The woody liana Secamone alpinii and Cryptolepis transvaalensis are frequently found in the tree and shrub strata.

The herbaceous layer has an average height of $0.5 \mathrm{~m}$ and an average canopy cover of $22 \%$. It is dominated by Cyperus albostriatus and Oplismenus hirtellus.

\section{General}

This community is closely related to the Celtis africana-Osyris lanceolata Kloof Forest described by Westfall (1981). These two communities have many distinctive habitat features and many, distinctive species in common. The Podocarpus latifolius-Rothmannia capensis Tall Forest is floristically related to the Widdringtonia nodiflora-
Podocarpus latifolius Short Forest, both being classified under the Podocarpus latifolius-Curtisia dentata Forest.

\subsection{Buxus macowanii-Kirkia wilmsii Low Forest}

Typical: relevé 64

Habitat

The Buxus macowanii-Kirkia wilmsii Low Forest is found at $1110 \mathrm{~m}-1250 \mathrm{~m}$ a.s.l. The Buxus macowanii-Kirkia wilmsii Low Forest is restricted to hot, dry kloofs of north facing, east and northwest-facing slopes (2$29^{\circ}$ ) of the study area (Fig. 1) This low forest occupies a relatively drier and warmer habitat than the Podocarpus latifolius-Curtisia dentata Forest.

The structure of this forest community is a low forest (Edwards 1983) and it occurs in the Ib Land Type (Land Type Survey Staff 1988). The soils are of the Mispah Form derived from sandstone of the Sandriviersberg Formation, and the soil is relatively shallow ( $<500 \mathrm{~mm}$ ) (Land Type Survey Staff 1988). Rocks cover more than $50 \%$ of the soil surface.

\section{Floristics and structure}

The Buxus macowanii-Kirkia wilmsii Low Forest is represented by four relevés and an average of 23 species was recorded per sample plot. It is differentiated by the following woody plant species (species group D): Buxus macowanii, Kirkia wilmsii, Apodytes dimidiata, Ochna pretoriensis, Croton gratissimus, Euphorbia turicalli, Acacia ataxacantha and Heteromorpha trifoliata.

The tree layer is on average $7.8 \mathrm{~m}$ tall, with an average canopy cover of $35 \%$. Other prominent trees are Mimusops zeyheri, Berchemia zeyheri, Dombeya rotundifolia (species group J) and Olea europaea subsp. africana, Cussonia paniculata and Euphorbia ingens (species group K).

The shrub layer is on average $2.3 \mathrm{~m}$ tall, with an average canopy cover of $84 \%$. Prominent shrubs occurring in this community are 
Ochna pretoriensis, Croton gratissimus, Euphorbia tirucallii and Acacia ataxacantha (species group D), Diospyros whyteana, and and Heteropyxis natalensis (species group K).

The herbaceous layer has an average height of $0.3 \mathrm{~m}$ and an average canopy cover of $7 \%$. The herbaceous layer is poorly represented and is dominated by the xerophytic ferns Cheilanthes viridis and Pellaea calomelanos (species group E).

General

Westfall (1981) described an Erythrina lysistemon-Celtis africana Kloof Forest with Buxus macowanii as a conspicuous woody species with more than $5 \%$ mean canopy cover and occurring in more than $50 \%$ of the relevés. This community is similar to the community found in the study area. These shrubs are often gregarious, forming pure stands (Table 1). The distribution of the tree/shrub, Buxus macowanii, is restricted to warm valleys and coastal dunes in the Eastern Cape, with the Limpopo Province population as an unexpected outlier (CoatesPalgrave 1983). This could indicate a former Afromontane forest biogeographic connection via the Waterberg and Stydpoort Mountains to the northeastern escarpment and also to the Blouberg and western Soutpansberg.

The Buxus macowanii-Kirkia wilmsii Dry Low Forest, a very specialised dry forest, representing a very rare and restricted plant community classified by Von Maltitz (2003) under Northern Highveld Forests. According to Von Maltitz (2003), these latter forests are restricted to Suikerbosrand (Bredenkamp \& Theron 1978, 1980), Witwatersrand (Behr \& Bredenkamp 1988; Ellery et al. 2001), Magaliesberg (Coetzee 1974, 1975), Waterberg (Westfall 1981; Westfall et al. 1985; Van Staden 2002), Sekhukhuneland (Siebert 2001), and some other ridges occurring throughout the western Central Bushveld region (Van Vuuren 1961; Van Vuuren \& Van der Schijff 1970; Van der Meulen 1979). These forest patches are imbedded within an ecotone between sourveld grasslands and subtropical savannas of the Central Bushveld.
2. Pappea capensis-Ziziphus mucronata Thickets and Bush Clumps

Dombeya rotundifolia subsp. rotundifolia, Berchemia zeyheri and Ziziphus mucronata (species group J) show strong floristic affinities between these thickets and the Buxus macowanii-Kirkia wilmsii Dry Low Forest.

\subsection{Rhus leptodictya-Mimusops zeyheri Termitarium Thickets}

Typical: relevé 18

Habitat

The Rhus leptodictya-Mimusops zeyheri Termitarium Thickets are found from $1160 \mathrm{~m}-$ $1300 \mathrm{~m}$ a.s.l. This widespread community occupies an even drier habitat than that of the Buxus macowanii-Kirkia wilmsii Low Forest, though the termitaria are moister than the surrounding savanna (Van der Meulen 1979). They are therefore classified with the forests. The bush clumps on termitaria are restricted to the Ad Land Type on level and gentle slopes (Land Type Survey Staff 1988) (Fig. 1).

Before proclamation of Marakele National Park, this community was subjected to heavy grazing by cattle and the field layer varies in height and cover depending on soil salinity and the amount of grazing (Coetzee et al. 1981). The vegetation developed on huge termite mounds to form this specific plant community. The size of these termitaria determines the type of vegetation that occurs. The trees are usually very tall because of the depth and aeration and the fine texture and higher nutrient status of the soil (Coetzee et al. 1976).

This community is a representative of Acocks' (1988) Sour Bushveld, with the structure as a short closed woodland (Edwards 1983)

\section{Floristics}

The Rhus leptodictya-Mimusops zeyheri Termitarium Thickets are differentiated by the following diagnostic plant species (species group G, Table 1): the woody Rhus lepto- 
dictya, Euclea crispa, Grewia flavescens, Flueggia virosa, Ficus thonningii and Pavetta zeyheri; the liana Asparagus transvaalensis; the grass Eragrostis curvula; the herbaceous Schistostephium heptalobum; and the weedy annual Tagetes minuta.

\subsubsection{Rhus leptodictya-Carissa bispinosa variation}

Typical: relevé 18

\section{Habitat}

The Rhus leptodictya-Carissa bispinosa variation is found at $1160 \mathrm{~m}-1300 \mathrm{~m}$ a.s.l. This variation occurs on level ground or/and gentle slopes $\left(1-160^{\circ}\right)$. The soils are yellow, apedal and well drained and relatively deep (> $500 \mathrm{~mm}$ ), belonging to one of the following forms: Inanda, Kranskop, Magwa, Hutton, Griffin and/or Clovelly (Land Type Survey Staff 1988) (Fig. 1).

The average diameter of the Rhus leptodictya-Carissa bispinosa variation bush clumps is $25 \mathrm{~m}$. It is represented by seven relevés and an average of 35 species was recorded per sample plot (Table 1).

Floristics and structure

The Rhus leptodictya-Carissa bispinosa variation is differentiated by the following diagnostic plant species (species group F, Table 1): the woody Carissa bispinosa, Gymnosporia buxifolia, Vangueria infausta, Clerodendrum glabrum, Adenia glauca, Dichrostachys cinerea, Gardenia volkensii, Psiadia punctulata, Aloe marlothii, Acacia karroo, Maerua angolensis and Pterocarpus rotundifolius; the forbs Pavonia burchelli, Sida dregei, Kalanchoe rotundifolia, Schkuhria pinnata, Lippia javanica, Sida cordiifolia, Anthospermum hispidulum, Ipomoea magnusiana, Hemizygia pretoriae, Solanum panduraeforme, Scadoxus puniceus; and the grasses Panicum maximum, Aristida congesta, Eragrostis rigidior, Eragrostis lehmanniana and Cynodon dactylon.

Many of these diagnostic species indicate previous over-utilisation and trampling.
The tree layer is on average $7 \mathrm{~m}$ tall with an average canopy cover of $79 \%$. Other prominent trees are Pappea capensis and Schotia brachypetala (species group I), Olea capensis (species group E), Mimusops zeyheri, Dombeya rotundifolia subsp. rotundifolia, Berchemia zeyheri and Ziziphus mucronata (species group J), and Olea europaea subsp. africana, Ficus sur, Cussonia paniculata and Grewia occidentalis (species group $\mathrm{K}$ ).

The shrub layer is on average $1.4 \mathrm{~m}$ tall, with an average canopy cover of $46 \%$. Prominent shrubs are Grewia flavescens, Flueggia virosa (species group $\mathrm{K}$ ) and Calpurnia aurea (species group $\mathrm{H}$ ).

The herbaceous layer has an average height of $0.4 \mathrm{~m}$ and an average canopy cover of $20 \%$. It is dominated by the grass Panicum maximum and Eragrostis rigidior, the forbs Pavonia burchelli, Schkuhria pinnata and Lippia javanica (species group F).

\section{General}

Coetzee et al. (1976) described similar communities from flat bottomlands with termitaria at Nylsvley Nature Reserve, namely the Pappea capensis-Acacia tortilis variation which shows strong affinities with the Rhus leptodictya-Carissa bispinosa variation, with the most common plant species being Carissa bispinosa and Pappea capensis.

\subsubsection{Rhus leptodictya-Berchemia zeyheri variation}

Typical: relevé 16

\section{Habitat}

The Rhus leptodictya-Berchemia zeyheri variation is found at $1250 \mathrm{~m}-1360 \mathrm{~m}$ a.s.l. The soils are the same as for the Rhus leptodictya-Carissa bispinosa variation, but here the bush clumps are much smaller, with an average diameter of $11 \mathrm{~m}$, whereas the average diameter of the bush clumps Rhus leptodictya-Carissa bispinosa variation is $25 \mathrm{~m}$.

Floristics and structure

This variation is represented by four relevés and an average of 35 species was recorded per sample plot. Although it seems that no 
diagnostic species occur in this variation, it can be distinguished from the Rhus leptodictya-Carissa bispinosa variation by the absence of species in the species group $\mathrm{F}$ and the presence of species in species group $\mathrm{H}$ (Table 1), with Maytenus undata, Calpurnea aurea and Calodendron capense being differential species.

The tree layer is on average $6.5 \mathrm{~m}$ tall with an average canopy cover of $66 \%$. The shrub layer is on average $1.6 \mathrm{~m}$ tall with an average canopy cover of $46 \%$. The herbaceous layer has an average height of $0.4 \mathrm{~m}$ and an average canopy cover of $10 \%$.

2.2 Olea europaea subsp. africana-Calpurnea aurea Tall Closed Woodland

Typical releve: relevé 97

Habitat

The Olea europaea subsp. africanaCalpurnea aurea Tall Closed Woodland is found from 1180-1500 m a.s.l. in deep kloofs on southwest-facing and south-facing sandstone slopes $\left(2-250^{\circ}\right)$, usually along seasonal streams (Table 1, Fig. 1). This bush clump community is a representative of Acocks' (1988) Sour Bushveld, with the structure as a tall closed woodland (Edwards 1983). It occurs on the Ad Land Type and the Ib Land Type (Fig. 2.7) (Land Type Survey Staff 1988). The soils are of the Mispah Form derived from sandstone of the Sandriviersberg Formation (Land Type Survey Staff 1988) and large rocks cover more than $31 \%$ of the soil surface (Fig. 1).

Floristics and structure

The Olea europaea subsp. africanaCalpurnea aurea Tall Closed Woodland is characterised by the presence of species group $\mathrm{H}$ and absence of species group $\mathrm{G}$. No diagnostic species group was identified, though the species of species group $\mathrm{H}$ are differential, it also indicates a floristic relationship with the Rhus leptodictyaBerchemia zeyheri variation (community 2.1.2). The differential species are the woody Maytenus undata, Calpurnia aurea, Calo- dendron capense, Gymnosporia polyacantha, Vepris lanceolata and Tricalysia lanceolata, the herbaceous Asparagus virgatus and the grass Setaria lindenbergiana.

The tree layer is on average $10.5 \mathrm{~m}$ tall with an average canopy cover of $56 \%$. Other prominent trees are Celtis africana (species group B); Rhus leptodictya, Euclea crispa, Ficus thonningii (species group G); Pappea capensis, Ziziphus mucronata, Zanthoxylum capense, Schotia brachypetala, Euclea natalensis and Acacia caffra (species group I); Mimusops zeyheri and Berchemia zeyheri (species group J); and Olea europaea subsp. africana, Ficus sur and Euphorbia ingens (species group $\mathrm{K}$ ).

The shrub layer is on average $1.8 \mathrm{~m}$ tall with an average canopy cover of $41 \%$. Cryptolepis transvaalensis is prominent.

The herbaceous layer has an average height of $0.4 \mathrm{~m}$ and an average canopy cover of $21 \%$. The herbaceous layer is dominated by the grass Setaria lindenbergiana and the forb Hypoestes forskaolii (species group K).

\section{General}

The Olea europaea subsp. africana-Calpurnia aurea Tall Closed Woodland has floristically strong affinities with the Rhus leptodictyaMimusops zeheri Termitarium Thickets (species group I) and especially the Rhus leptodictya-Berchemia zeyheri variation, indicated by species group $\mathrm{H}$. The habitat difference between these two bush clump communities is that the Olea europaea subsp. africana-Calpurnia aurea Tall Closed Woodland occurs in deep, sheltered kloofs on rocky substrates without termitaria, while the Rhus leptodictya-Berchemia zeyheri variation occurs on termitaria on the plains without rocks.

\section{Discussion}

According to White (1978) the majority of the tree species in the Afromontane forests are very widespread. Amongst them are Podocarpus latifolius, Ilex mitis and Halleria lucida that occur in the study area. These 
species could almost be used to define the Afromontane region as a whole. Not one species occurs throughout, but most species of the assemblage are represented on virtually every 'island' of Afromontane forest.

According to Von Maltitz (2003) the Northern Highveld Forest type is a relict forest type in a progressed stage of 'erosion' from the original Afromontane composition. They are considered remnants of the Magaliesburg Extension (White 1978) —an Afromontane (forest) intrusion linking the forests of Northern Escarpment to those found in sheltered sites of the Central Bushveld and Northern Highveld regions. These forests are Afrotemperate (Afromontane) in character, however Holocene climate changes have caused their confinement to fire-sheltered habitats and a concomitant decline in forest elements, but an increase in woodland elements (Von Maltitz 2003).

This fragmentary Afromontane type forest forms transitions to surrounding savanna and to the riverine forests with Combretum erythrophyllum (Van Rooyen 1983; Von Maltitz 2003). There is also floristic similarity between the kloof forest communities and thickets found on termitaria. Termitaria are known to increase water infiltration and percolation, as well as nutrient availability, compared to the surrounding savanna woodlands (Van der Meulen 1979). Therefore, termitaria do support dense thickets with savanna species, however some forest species are also present.

Low diversity of the woody element places this type close to Drakensberg Montane Forests and Northern KwaZulu-Natal Mistbelt Forests (Von Maltitz 2003).

The distribution of the shrub Buxus macowanii is of biogeographic interest. This species is restricted to coastal forests of the Eastern Cape and forms an outlying population in the Waterberg region (Coates Palgrave 1983).

\section{Acknowledgements}

South African National Parks is thanked for the opportunity to use the offical research project for a MSc degree.

\section{References}

AcocKs, J.P.H. 1988. Veld types of South Africa, 3rd edn. Memoirs of the botanical Survey of South Africa 57: 1-146.

Barkman, J.J., J. Moravec \& S. Rauchert. 1964. Kritische Bemerkungen und Vorschläge zur quantitativen Vegetationanalyse. Acta Botanica Neerlandia 13: 394-449.

BeHR, C.M. \& G.J. BREDENKAMP. 1988. A phytosociological classification of the Witwatersrand National Botanical Garden. South African Journal of Botany 54: 525-533.

Bezuidenhout, H., H.C.Biggs \& G.J. BREDENKAMP. 1996. A process supported by the utility BBPC for analysing Braun-Blanquet data on a personal computer. Koedoe 39(1): 107-112.

BredenKAmp, G.J. \& L.R. Brown. 2003. A reappraisal of Acocks' Bankenveld: Origin and diversity of vegetation types. South African Journal of Botany 69(1): 7-26.

BredenKAMP, G.J. \& G.K. Theron. 1978. A synecological account of the Suikerbosrand Nature Reserve. 1. The phytosociology of the Witwatersrand geological system. Bothalia 12: 513-529.

BredENKAMP, G.J. \& G.K. Theron. 1980. A synecological account of the Suikerbosrand Nature Reserve, Part II: The phytosociology of the Ventersdorp geological system. Bothalia 13(1\&2): 199-216.

Coates Palgrave, K. 1983. Trees of Southern Africa. 2nd ed. Cape Town: Struik.

CoetzeE, B.J. 1974. A phytosociological classification of the vegetation of the Jack Scott Nature Reserve. Bothalia 11: 329 - 347.

CoetzeE, B.J. 1975. A phytosociological classification of the Rustenburg Nature Reserve. Bothalia 11: 561-580.

Coetzee, B.J., F. van der Meulen, S. Zwanziger, P. Gonsalves \& P.J.Weisser. 1976. A phytosociological classification of the Nylsvley Nature Reserve. Bothalia 12: 137-160.

Coetzee, B.J., P. VAn WyK, W.P.D. GerTenbach, A. Hall-Martin \& S.C.J. Joubert. 1981. 'n Plantekologiese verkenning van die Waterberggebied in die Noord-Transvaalse Bosveld. Koedoe 24:1-23.

Du Preez, P.J., G.J.Bredenkamp \& H.J.T. Venter. 1991. The syntaxonomy and synecology of the forests in the eastern Orange Free State, South Africa. I. The Podocarpetalia latifolii. South African Journal of Botany 57: 198-206. 
EDWARDS, D. 1983. A Broad-scale structural classification of vegetation for practical purposes. Bothalia 14 (3 \& 4): 705-712.

Ellery, W.N., K. BALKWILl \& K. Ellery, R.A. REDDY. 2001. Conservation of the vegetation on the Melville Ridge, Johannesburg. South African Journal of Botany 67: 261-273.

GelDENHUYS, C.J. 1994. Bergwind patches and the location of forest patches in the southern Cape landscape South Africa. Journal of Biogeography 21: 49-62.

GERTENBACH, W.P.D. 1987. 'n Ekologiese studie van die Suidelikste Mopanieveld in die Nasionale Krugerwildtuin. D.Sc proefskrif, Universiteit van Pretoria, Pretoria.

HILL, M.O. 1979. TWINSPAN - a Fortran program for arranging multivariate data in an ordered two way table by classification of individuals and attributes. Ithaca, New York: Cornell University.

Land Type Survey StafF. 1988. Land types of the maps 2426 Thabazimbi, 2428 Nylstroom. Memoirs of the agricultural natural Resoures of South Africa No.10: 1-431.

Mucina, L. \& P.J. VAn Staden. 2003. Marakele Afromontane Forests. Pp. 99-104. In: VoN Maltitz, G. (Project leader). Classification system for South African indigenous forests: An objective classification for the Department of Water Affairs and Forestry. Pretoria: Council for Scientific and Industrial Research. (Environmentek report ENV-P-C 2003-017).

Mueller-Dombois, D. \& H. EllenBerg. 1974. Aims and Methods of Vegetation Ecology. New York: Wiley.

Rutherford, M.C. \& R.H. WestFall. 1994. Biomes of southern Africa: An objective categorization. Memoirs of the Botanical Survey of South Africa 63: 1-94.

SIEBERT, S.J. 2001. Vegetation of the ultramafic soils of the Sekhukhuneland Centre of Endemism. Ph.D. thesis, Universty of Pretoria, Pretoria.

VAn Der Meulen, F. 1979. Plant sociology of the Western Transvaal Bushveld. South Africa: Syn- taxonomic and synecological study. Vaduz: Cramer. (Dissertationes Botanica 49.)

Van Rooyen, N. 1983. Die Plantegroei van die Roodeplaatdam-natuurreservaat II. Die plantgemeenskappe. South African Journal of Botany 2: 115-125.

Van Staden, P. J. 2002. An Ecological Study of the Plant Communities of the Marakele National Park. M.Sc. thesis, University of Pretoria, Pretoria.

VAn Staden P.J. \& G.J. BredenKamp. 2005. Major plant communities of the Marakele National Park. Koedoe 48(2): 59-70.

VAN VuUREN, D.R.J. 1961. 'n Ekologiese studie van 'n noordelike en suidelike kloof van die Magaliesberge. M.Sc. thesis, Universty of Pretoria, Pretoria.

VAN VuUREN, D.R.J. \& H.P. VAN DER SCHIJFF. 1970. 'n Vergelykende ekologiese studie van die plantegroei van 'n noordelike en suidelike kloof van die Magaliesberg. Tydskrif vir Natuurwetenskappe 10: 16-75.

Von Maltitz, G. (Project leader). 2003. Classification system for South African indigenous forests: An objective classification for the Department of Water Affairs and Forestry. Pretoria: Council for Scientific and Industrial Research. (Environmentek report ENV-P-C 2003-017).

WERGER, M.J.A. 1974. On concepts and techniques applied in the Zürich-Montpellier method of vegetation survey. Bothalia 11(3): 309-323.

WESTFALL, R.H. 1981. The plant ecology of the farm Groothoek, Thabazimbi District. M.Sc. thesis, University of Pretoria, Pretoria.

Westfall, R.H., N. van RoOyen \& G.K. Theron. 1985. The plant ecology of the farm Groothoek, Thabazimbi District. 2. Classification. Bothalia 15: 655-688.

White, F. 1978. The Afromontane region. Pp. 465-513. In: Werger, M.J.A. (ed.). Biogeography and ecology of Southern Africa. The Hague: Junk. 